\title{
Nitric Oxide Turn-on Fluorescent Probe Based on Deamination of Aromatic Primary Monoamines
}

\author{
Tsun-Wei Shiue, ${ }^{\dagger}$ Yen-Hao Chen ${ }^{\dagger}$ Chi-Ming Wu, ${ }^{\ddagger}$ Gyan Singh ${ }^{\dagger}$ Hsing-Yin Chen ${ }^{\ddagger}$ Chen-Hsiung Hung, ${ }^{\S}$ \\ Wen-Feng Liaw," and Yun-Ming Wang*, \\ ${ }^{\dagger}$ Department of Biological Science and Technology, Institute of Molecular Medicine and Bioengineering, National Chiao Tung \\ University, 75 Bo-Ai Street, Hsinchu 300, Taiwan \\ ${ }^{\ddagger}$ Department of Medicinal and Applied Chemistry, Kaohsiung Medical University, 100 Shih-Chuan first Road, Kaohsiung 807, Taiwan \\ ${ }^{\S}$ Institute of Chemistry, Academia Sinica, 128 Academia Road Sec. 2, Nankang, Taipei 115, Taiwan \\ "Department of Chemistry, National Tsing Hua University, 101 Kuang-Fu Road Sec. 2, Hsinchu 300, Taiwan
}

Supporting Information

ABSTRACT: The stable, water-soluble, and nonfluorescent FAOMe can sense nitric oxide (NO) and form the intensely fluorescent product dA-FA-OMe via reductive deamination of the aromatic primary amine. The reaction is accompanied by a notable increase of the fluorescent quantum yield from 1.5 to $88.8 \%$. The deamination mechanism of FA-OMe with $\mathrm{NO}$ was proposed in this study. The turn-on fluorescence signals were performed by suppression of photoinduced electron transfer (PeT), which was demonstrated by density functional theory (DFT) calculations of the components forming FA-OMe and dA-FA-OMe. Furthermore, FA-OMe showed water solubility and good stability at physiological pHs. Moreover, the selectivity study indicated that FA-OMe had high specificity for $\mathrm{NO}$ over other reactive oxygen/nitrogen species. In an endogenously

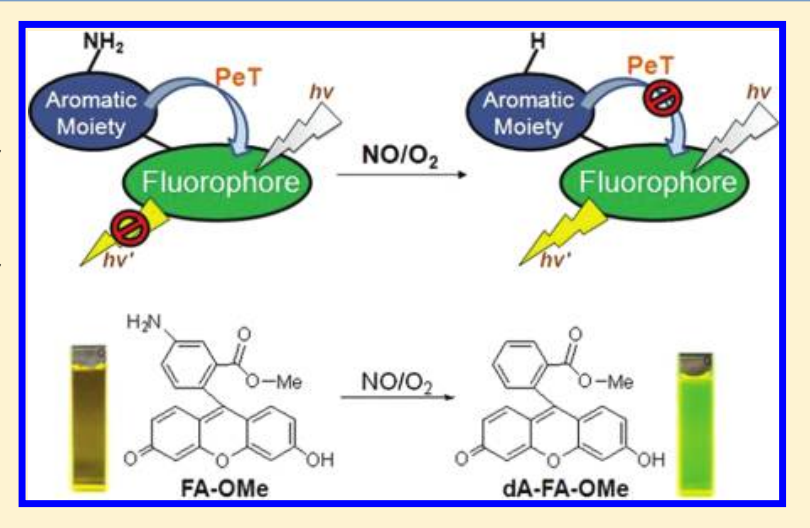
generated NO detection study, increasing the incubation time of FA-

OMe with lipopolysaccharide (LPS) pretreated Raw 264.7 murine macrophages could cause an enhanced fluorescence intensity image. In addition, a diffusion/localization cell imaging study showed that FA-OMe could be trapped in Raw 264.7 cells. These cell imaging results demonstrated that FA-OMe could be used as a turn-on fluorescent sensor for the detection of endogenously generated NO.

\section{INTRODUCTION}

Nitric oxide (NO), produced by nitric oxide synthases in the biological systems, has been known as a ubiquitous signaling molecule. Despite being a simple molecule, NO is involved in diverse physiological and pathological pathways. ${ }^{1}$ Although NO is a key vertebrate biological messenger, the mechanisms by which it performs its diverse biological roles remain elusive. In order to comprehend the diverse biological roles of $\mathrm{NO}$, several techniques such as chemiluminescence, ${ }^{2}$ colorimetry, ${ }^{3}$ electron paramagnetic resonance, ${ }^{4}$ electrochemistry, ${ }^{5}$ and fluorimetry ${ }^{6}$ have been developed. In view of its sensitivity, selectivity, spatiotemporal resolution, and experimental feasibility, fluorimetry, which exploits fluorescent probes to monitor analytes of interest under a fluorescence microscope, has been regarded as a most promising method to detect endogenous NO. There have been a number of small-molecule organic or inorganic fluorescent NO sensors reported to date. ${ }^{7}$ A two-component system comprised of an NO-reactive moiety coupling to an organic fluorophore has been widely investigated to develop NO-responsive organic molecule based sensors. The NOreactive moiety acts as a modulator in the photoinduced electron transfer (PeT) mechanism. ${ }^{8}$ After reaction with $\mathrm{NO}$ or the NO oxidized products, the PeT fluorescence quenching property is suppressed and the fluorescence of the probe is restored. The $o$-diaminophenyl group is the most commonly used NO-reactive moiety in organic fluorescent probes. ${ }^{9}$ The electron-rich $o$-diaminophenyl group can react with NO under aerobic conditions to produce fluorescent triazole derivatives. However, there are some undesired handicaps, such as complicated and low-yield synthetic procedures and blank fluorescence, existing in these kinds of NO probes.

In this study, the possibility of using an aromatic primary monoamine moiety as an NO-reactive site for the modulation of PeT was explored. The basic concept is outlined in Figure 1. The study was inspired by the genotoxic effects of NO. The NO-induced deamination of cytosine, adenine, guanine, and 5methylcytosine indeed represents an important NO-induced genotoxic mechanism. ${ }^{10}$ In addition, previous research reported that some aromatic amines react with $\mathrm{NO}$ or $\mathrm{N}_{2} \mathrm{O}_{3}$ to give the

Received: February 20, 2012

Published: April 9, 2012 


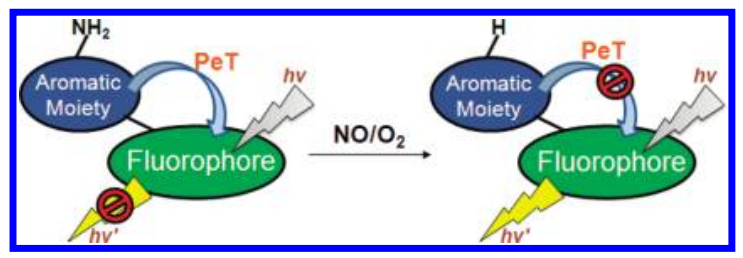

Figure 1. An NO turn-on probe through NO-induced deamination of an aromatic primary amino group.

corresponding deaminated aromatics. ${ }^{11}$ In addition, it was reported that fluorescence of a fluorescent molecule could be adjusted by changing the electronic influence of the nitrogen electron lone pair. ${ }^{12}$ Therefore, we have investigated the ability of NO to deaminate the aromatic primary amino group, thereby altering the electronic influence of the aromatic moiety on the fluorophore. To the best of our knowledge, a NO turnon fluorescent probe through reductive deamination of an aromatic primary monoamine has never been reported.

Among the various aromatic amines, we prefer aromatic amino esters to be the NO-reactive moieties. The ester functionality can enhance the cellular uptake of a probe and ensure its trappability within the plasma membrane. ${ }^{13}$ In the current study, 5-amino-2-(6-hydroxy-3-oxo-3H-xanthen-9-yl)benzoic acid methyl ester (FA-OMe) was synthesized as an NO turn-on fluorescent probe. The reaction product (dA-FA-OMe) of FA-OMe with NO under aerobic conditions was identified, and a possible reaction mechanism was proposed. The DFT calculations of dA-FA-OMe relative to FA-OMe were undertaken to interpret the PeT phenomenon. For realizing the level of fluorescence enhancement, the fluorescent properties of FA$\mathrm{OMe}$ and dA-FA-OMe were studied and compared. In order to confirm their stability, the fluorescence intensities of FA-OMe and $\mathrm{dA}-\mathrm{FA}-\mathrm{OMe}$ under various $\mathrm{pH}$ conditions were measured. To comprehend the NO-detecting ability, time- and concentration-dependent studies were also investigated. In addition, the selectivity of FA-OMe for NO against other reactive oxygen and nitrogen species was investigated. Furthermore, in vitro fluorescence images were obtained.

\section{EXPERIMENTAL SECTION}

2.1. Materials and Instruments. All chemicals were obtained from commercial suppliers and used as received without further purification. Hydrogen peroxide $\left(\mathrm{H}_{2} \mathrm{O}_{2}\right)$, dehydroascorbic acid (DHA), ascorbic acid (AA), ethylenediaminetetraacetic acid (EDTA), lipopolysaccharide (LPS), and fluoresceinamine were purchased from Sigma-Aldrich. Sodium nitrite $\left(\mathrm{NaNO}_{2}\right)$ and sodium nitrate $\left(\mathrm{NaNO}_{3}\right)$ were purchased from Showa. Angeli's salt $\left(\mathrm{Na}_{2} \mathrm{~N}_{2} \mathrm{O}_{3}\right)$ and sodium peroxynitrite $(\mathrm{ONOONa}$, as a solution in $0.3 \mathrm{M} \mathrm{NaOH})$ were purchased from Cayman Chemical Co. 4-(2Hydroxyethyl)-1-piperazineethanesulfonic acid (HEPES, free acid, Ultrapure Bioreagent) was purchased from MP Biomedicals. Ferrous ammonium sulfate hexahydrate $\left(\mathrm{Fe}\left(\mathrm{NH}_{4}\right)_{2}\left(\mathrm{SO}_{4}\right)_{2} \cdot 6 \mathrm{H}_{2} \mathrm{O}\right)$ was purchased from J. T. Baker. Dulbecco's Modified Eagle Medium (DMEM) and sodium pyruvate were purchased from Cellgro. Fetal bovine serum (FBS, 10\%) was purchased from HyClone. NO(g) (10\% $\mathrm{NO} / 90 \% \mathrm{~N}_{2}$ ) was purchased from SanFu. It was passed through an Ascarite II column to remove higher nitrogen oxides before use. ${ }^{14}$ Deionized water was produced by a Milli-Q reagent water purification system. Methanol was distilled over $\mathrm{Mg} / \mathrm{I}_{2}$ and subsequently dried over $0.3 \mathrm{~nm}$ molecular sieves. Preparative thin-layer chromatographic (TLC) plates were prepared from silica gel (Macherey-Nagel). ${ }^{1} \mathrm{H}$ and ${ }^{13} \mathrm{C}$ NMR spectra were obtained on a Varian VXR-300 spectrometer at 300 and $75 \mathrm{MHz}$ and were referenced to the internal ${ }^{1} \mathrm{H}$ and ${ }^{13} \mathrm{C}$ solvent peaks. ESI-LRMS spectra were recorded on a Micromass Q-
Tof mass spectrometer. EI-HRMS spectra were recorded on a Finnigan/Thermo Quest MAT mass spectrometer. UV/vis absorption spectra were recorded on a Hitachi U-3000 spectrophotometer. Bright-field and fluorescence images were recorded on an Olympus IX71 fluorescence microscope equipped with a $100 \mathrm{~W}$ mercury lamp, B-2A filters, and a color CCD camera system.

2.2. Preparation of 5-Amino-2-(6-hydroxy-3-oxo-3H-xanthen-9-yl)benzoic Acid Methyl Ester (FA-OMe). A modification of the synthetic procedure of FA-OMe was employed. ${ }^{15}$ A mixture of fluoresceinamine $(200 \mathrm{mg}, 0.576 \mathrm{mmol}), \mathrm{MeOH}(10 \mathrm{~mL})$, and concentrated $\mathrm{H}_{2} \mathrm{SO}_{4}$ solution $(0.2 \mathrm{~mL})$ was heated for $48 \mathrm{~h}$ under reflux. The solution was poured on ice $(300 \mathrm{~g})$, and then a saturated $\mathrm{NaHCO}_{3}$ solution was slowly added to adjust the $\mathrm{pH}$ to 6.5 . An orange precipitate was separated by centrifugation and then subjected to TLC, with $\mathrm{MeOH} / \mathrm{CH}_{2} \mathrm{Cl}_{2}$ as eluant $(1 / 12, \mathrm{v} / \mathrm{v})$. A yellow band was isolated and identified as 5-amino-2-(6-hydroxy-3-oxo-3H-xanthen-9-yl)benzoic acid methyl ester (FA-OMe; $184 \mathrm{mg}, 88.5 \%)$. ESI-LRMS: $m / z$ 362.1 $\left([\mathrm{M}+\mathrm{H}]^{+}\right), \mathrm{M}^{+}$calculated 361.1. ${ }^{1} \mathrm{H}$ NMR $\left(\mathrm{DMSO}-d_{6}\right): \delta$ $7.30(\mathrm{~s}, 1 \mathrm{H}), 7.00(\mathrm{~d}, J=9.0 \mathrm{~Hz}, 1 \mathrm{H}), 6.90(\mathrm{~d}, J=9.0 \mathrm{~Hz}, 1 \mathrm{H}), 6.77$ $(\mathrm{d}, J=9.0 \mathrm{~Hz}, 2 \mathrm{H}), 6.30(\mathrm{~d}, J=9.0 \mathrm{~Hz}, 2 \mathrm{H}), 6.23(\mathrm{~s}, 2 \mathrm{H}), 5.81(\mathrm{br} \mathrm{s}$, $2 \mathrm{H}), 3.49(\mathrm{~s}, 3 \mathrm{H}) .{ }^{13} \mathrm{C}$ NMR (DMSO- $\left.d_{6}\right): \delta 178.4,166.2,157.3,152.9$, $149.7,131.5,130.8,129.8,122.8,120.7,117.0,114.7,111.1,103.1$, 51.9.

2.3. Reaction of FA-OMe with $\mathrm{NO} / \mathrm{O}_{2}$. In $100 \mathrm{~mL}$ of an FA-OMe $(30 \mathrm{mg}, 0.083 \mathrm{mmol}$ ) solution in $100 \mathrm{mM}$ HEPES buffer at $\mathrm{pH} 7.4$, $10 \%$ NO gas was bubbled under aerobic conditions at room temperature. The reaction was terminated using TLC to ensure the consumption of all of FA-OMe. Then the solvent was removed on a rotary evaporator. The residue was subjected to TLC, with $\mathrm{MeOH}$ / $\mathrm{CH}_{2} \mathrm{Cl}_{2}$ as eluant $(1 / 10, \mathrm{v} / \mathrm{v})$. The first bright yellow band was isolated and identified as 2-(6-hydroxy-3-oxo-3H-xanthen-9-yl)benzoic acid methyl ester (dA-FA-OMe; $22.4 \mathrm{mg}, 78.0 \%$ ). ESI-LRMS: $\mathrm{m} / z 347.1$ $\left([\mathrm{M}+\mathrm{H}]^{+}\right), \mathrm{M}^{+}$calculated 346.1. EI-HRMS: $m / z 346.0836\left(\mathrm{M}^{+}\right), \mathrm{M}^{+}$ calculated 346.0841. ${ }^{1} \mathrm{H}$ NMR (DMSO- $\left.d_{6}\right): \delta 8.12(\mathrm{~d}, J=7.8 \mathrm{~Hz}, 1 \mathrm{H})$, $7.80(\mathrm{dd}, J=7.5$ and $7.8 \mathrm{~Hz}, 1 \mathrm{H}), 7.71(\mathrm{dd}, J=7.5$ and $7.8 \mathrm{~Hz}, 1 \mathrm{H})$, $7.40(\mathrm{~d}, J=7.5 \mathrm{~Hz}, 1 \mathrm{H}), 6.59$ (d, $J=9.0 \mathrm{~Hz}, 2 \mathrm{H}), 6.30(\mathrm{~m}, 4 \mathrm{H}), 3.54$ $(\mathrm{s}, 3 \mathrm{H}) .{ }^{13} \mathrm{C}$ NMR (DMSO-d $): \delta 178.7,165.5,157.2,151.3,134.8$, $132.7,130.7,130.3,129.8,129.5,129.3,123.2,110.3,103.4,52.2$.

2.4. Reaction of Fluoresceinamine with $\mathrm{NO} / \mathrm{O}_{2}$. In $45 \mathrm{~mL}$ of a fluoresceinamine $(10 \mathrm{mg}, 0.029 \mathrm{mmol})$ solution in $100 \mathrm{mM}$ HEPES buffer at $\mathrm{pH} 7.4,10 \% \mathrm{NO}$ gas was bubbled under aerobic conditions at room temperature. The reaction was terminated using TLC to ensure the consumption of all of fluoresceinamine. Then the solvent was removed on a rotary evaporator. The residue was subjected to TLC, with $\mathrm{MeOH} / \mathrm{CH}_{2} \mathrm{Cl}_{2}$ as eluant $(1 / 10, \mathrm{v} / \mathrm{v})$. The first bright yellow band was isolated and identified as fluorescein $(7.54 \mathrm{mg}, 78.3 \%)$.

2.5. Preparation of NO Stock Solutions. The preparation of NO and its stock solutions were carried out according to the reported methods. ${ }^{16}$ NO could be generated by slowly dropping $2.0 \mathrm{M}$ $\mathrm{H}_{2} \mathrm{SO}_{4}(\mathrm{aq})$ into a glass flask containing a saturated $\mathrm{NaNO}_{2}$ water solution. Since $\mathrm{O}_{2}$ will rapidly oxidize $\mathrm{NO}$ to form $\mathrm{NO}_{2}$, all apparatus were carefully degassed with argon for $30 \mathrm{~min}$ to remove $\mathrm{O}_{2}$. The forming gas was passed twice through a $30 \% \mathrm{NaOH}$ solution and once through water to trap $\mathrm{NO}_{2}$ generated from the reaction of $\mathrm{NO}$ with traces of $\mathrm{O}_{2}$. To produce a saturated $\mathrm{NO}$ solution $\left(1.8 \mathrm{mM}\right.$, at $\left.20^{\circ} \mathrm{C}\right)$ as a stock solution, $10 \mathrm{~mL}$ of deoxygenated deionized water was bubbled with NO for $30 \mathrm{~min}$ and kept under an NO atmosphere. The saturation concentration was ascertained by using the Griess method. ${ }^{3 a}$ Stock solutions were freshly prepared for each experiment and stored in a glass flask with a rubber septum.

2.6. Fluorometric Analysis. Fluorescence spectra were recorded by using a Hitachi F-7000 spectrophotometer. The slit widths were 5.0 and $2.5 \mathrm{~nm}$ for excitation and emission, respectively. The photon multiplier voltage was $500 \mathrm{~V}$. Spectra were routinely acquired at $25.0 \pm$ $0.1{ }^{\circ} \mathrm{C}$ in quartz cuvettes with a volume of $3.5 \mathrm{~mL}$.

2.6.1. Fluorescence Quantum Yield Determination. Fluorescence quantum yields of FA-OMe and dA-FA-OMe were measured in $0.1 \mathrm{M}$ $\mathrm{NaOH}(\mathrm{aq})$ by using fluorescein $\left(\Phi_{\mathrm{fl}}=0.95\right.$ in $\left.0.1 \mathrm{M} \mathrm{NaOH}(\mathrm{aq})\right)$ as a standard. ${ }^{12 \mathrm{~b}}$ Fluorescence quantum yields were calculated by use of the following equation: $\Phi_{\text {unk }}=\Phi_{\text {std }}\left(I_{\text {unk }} / A_{\text {unk }}\right)\left(A_{\text {std }} / I_{\text {std }}\right)\left(n_{\text {unk }} / n_{\text {std }}\right)^{2}$, where 


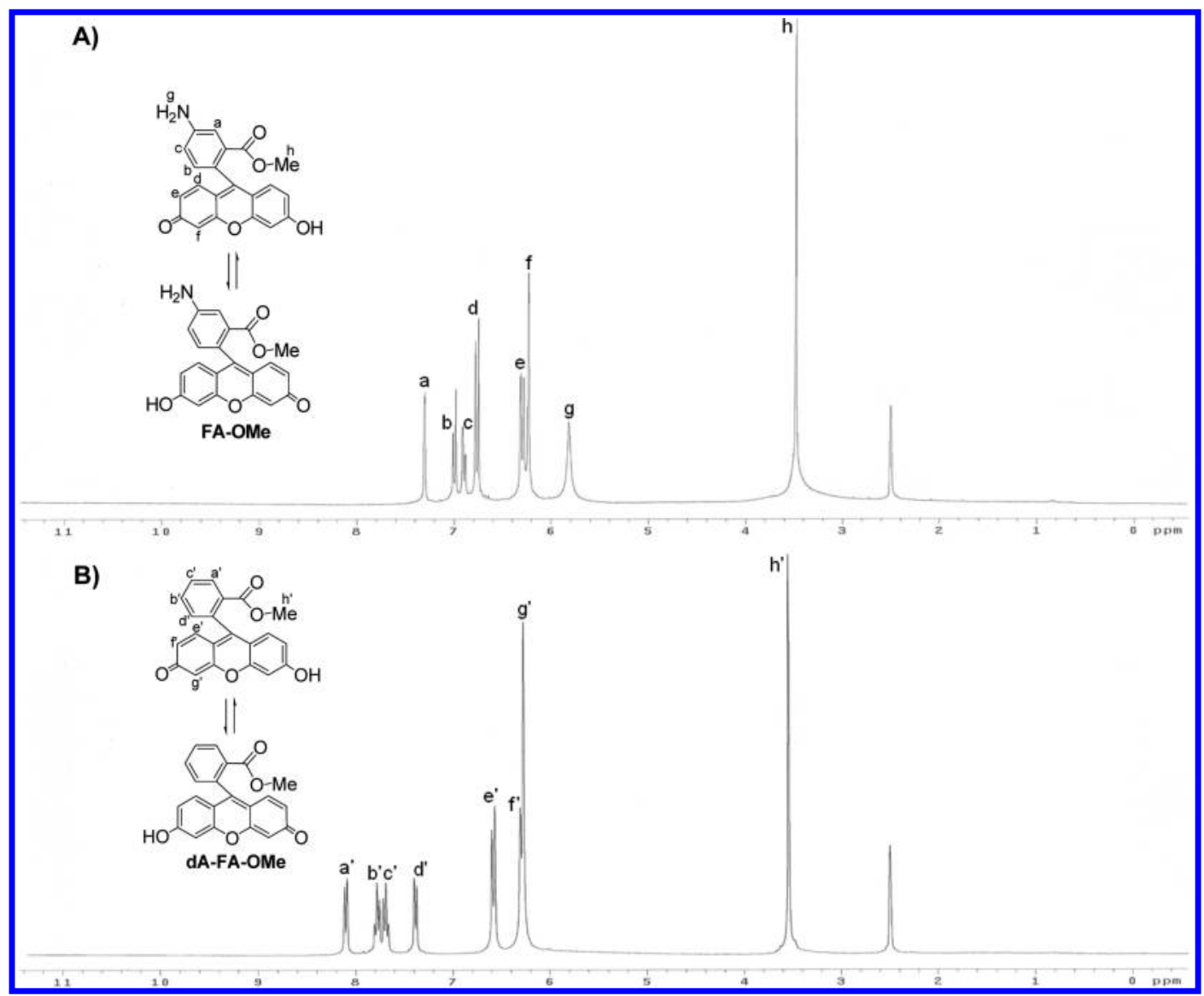

Figure 2. ${ }^{1} \mathrm{H}$ NMR spectra of FA-OMe (A) and dA-FA-OMe (B) in $d_{6}$-DMSO at $25.0 \pm 0.1{ }^{\circ} \mathrm{C}$.

$\Phi_{\text {unk }}$ is the fluorescence quantum yield of the sample, $\Phi_{\text {std }}$ is the fluorescence quantum yield of the standard, $I_{\text {unk }}$ and $I_{\text {std }}$ are the integrated emission intensities of the sample and the standard, respectively, $A_{\text {unk }}$ and $A_{\text {std }}$ are the absorbances of the sample and the standard at the excitation wavelength, respectively, and $n_{\text {unk }}$ and $n_{\text {std }}$ are the refractive indexes of the corresponding solutions, respectively.

2.6.2. Stability Studies of FA-OMe, $d A-F A-O M e$, and Fluoresceinamine. Solutions of $20 \mu \mathrm{M}$ FA-OMe in $100 \mathrm{mM}$ HEPES in the $\mathrm{pH}$ range $6-10$ were prepared by mixing $0.2 \mathrm{~mL}$ of $500 \mu \mathrm{M}$ solutions of FA-OMe in deionized water with $4.8 \mathrm{~mL}$ of $100 \mathrm{mM}$ HEPES whose $\mathrm{pH}$ values were adjusted by hydrogen chloride and sodium hydroxide. Solutions of $20 \mu \mathrm{M}$ dA-FA-OMe and $20 \mu \mathrm{M}$ fluoresceinamine in 100 $\mathrm{mM}$ HEPES in the $\mathrm{pH}$ range 6-10 were prepared as described above. The fluorescence intensities of FA-OMe, dA-FA-OMe, and fluoresceinamine were measured after $2 \mathrm{~h}$ of mixing $\left(\lambda_{\mathrm{ex}} 460 \mathrm{~nm}, \lambda_{\mathrm{em}} 524\right.$ $\mathrm{nm})$.

2.6.3. Selectivity Studies. All the fluorescence tests were performed in $100 \mathrm{mM}$ HEPES buffer at $\mathrm{pH} 7.4$ and $25.0 \pm 0.1{ }^{\circ} \mathrm{C}$. The fluorescence intensities were monitored after reacting $3 \mathrm{~mL}$ of $20 \mu \mathrm{M}$ FA-OMe (in $100 \mathrm{mM}$ HEPES buffer at $\mathrm{pH} 7.4$ ) with 100 equiv of reactive oxygen species (ROS), reactive nitrogen species (RNS), ascorbic acid (AA), and dehydroascorbic acid (DHA) for $2 \mathrm{~h}$, respectively $\left(\lambda_{\mathrm{ex}} 460 \mathrm{~nm}, \lambda_{\mathrm{em}} 524 \mathrm{~nm}\right)$. The concentration of the $\mathrm{ONOO}^{-}$stock solution was calculated by using its molar extinction coefficient of $1670 \mathrm{M}^{-1} \mathrm{~cm}^{-1}$ at $302 \mathrm{~nm} .{ }^{17}$ The degassed aqueous solutions of Angeli's salt were freshly prepared under anaerobic conditions and used as a nitroxyl (HNO) source. ${ }^{18}$ Hydroxyl radical $(\bullet \mathrm{OH})$ was produced by reacting ferrous ammonium sulfate hexahydrate $\left(\mathrm{Fe}\left(\mathrm{NH}_{4}\right)_{2}\left(\mathrm{SO}_{4}\right)_{2} \cdot 6 \mathrm{H}_{2} \mathrm{O}\right)$ with $\mathrm{H}_{2} \mathrm{O}_{2}$ under anaerobic conditions. ${ }^{19}$ Hydrogen peroxide $\left(\mathrm{H}_{2} \mathrm{O}_{2}\right)$ was diluted promptly from the $30 \% \mathrm{H}_{2} \mathrm{O}_{2}$ solution and quantified by measuring its absorbance at $240 \mathrm{~nm}$ with a molar absorption coefficient of $43.6 \mathrm{M}^{-1} \mathrm{~cm}^{-1}$. ${ }^{20}$ The aqueous solutions of $\mathrm{NaNO}_{2}$ and $\mathrm{NaNO}_{3}$ were freshly prepared and used as nitrite $\left(\mathrm{NO}_{2}^{-}\right)$and nitrate $\left(\mathrm{NO}_{3}^{-}\right)$sources, respectively. The nitrogen-purged aqueous solutions of AA and DHA in $100 \mathrm{mM}$ HEPES buffer at $\mathrm{pH} 7.4$ containing $3 \mathrm{mM}$ EDTA were freshly prepared before use. $^{21}$

2.7. Computational Methods. Density functional theory (DFT) calculations at the B3LYP/6-31++G** level were used to obtain optimized geometries and energy levels of frontier molecular orbitals for methyl 3-aminobenzoate, methyl benzoate, and xanthene, the components forming FA-OMe and dA-FA-OMe. The hydration effect on energy levels was considered by performing single-point energy calculations with the polarizable continuum model on gas-phase optimized structures. All calculations were carried out with the Gaussian 09 program. ${ }^{22}$

2.8. Cell Culture and In Vitro Cell Imaging. Raw 264.7 murine macrophage is organized from tumor ascites induced by intraperitoneal injection of Abselon Leukemia Virus (A-MuLV) in male mice. Raw 264.7 murine macrophages were obtained from the American Type Culture Collection (Manassas, VA). The cells were cultured in DMEM and supplemented with $10 \%$ FBS, $1 \%$ sodium pyruvate, and $1 \%$ MEM nonessential amino acids at $37{ }^{\circ} \mathrm{C}$ under a humidified 5\% $\mathrm{CO}_{2}$ atmosphere. For imaging studies, Raw 264.7 murine macrophages were passed and plated into poly-D-lysine coated plates containing $2 \mathrm{~mL}$ of DMEM and incubated at $37^{\circ} \mathrm{C}$ with $5 \%$ $\mathrm{CO}_{2}$. For endogenously generated nitric oxide detection studies, iNOS (inducible nitric oxide synthase) was induced in Raw 264.7 murine macrophages with $0.5 \mu \mathrm{g} \mathrm{mL}^{-1}$ of LPS for $4 \mathrm{~h}$, and the cells were then coincubated with $10 \mu \mathrm{M}$ of FA-OMe for 4 and $8 \mathrm{~h}$. Prior to imaging, the cells were washed three times with $1 \mathrm{~mL}$ of PBS and then bathed in $2 \mathrm{~mL}$ of PBS. The fluorescence alterations were monitored by the fluorescence microscope. For FA-OMe diffusion/localization studie$\mathrm{s},{ }^{13 a}$ Raw 264.7 murine macrophages were prestimulated with $1.25 \mu \mathrm{g}$ $\mathrm{mL}^{-1}$ of LPS for $4 \mathrm{~h}$, and then the cells were coincubated with $10 \mu \mathrm{M}$ of FA-OMe for $8 \mathrm{~h}$. The cells were washed three times with $1 \mathrm{~mL}$ of PBS prior to imaging and then bathed in $2 \mathrm{~mL}$ of PBS during the imaging procedure. To mimic media flow, the PBS was removed, and 
Scheme 1. Proposed Mechanism of FA-OMe with NO under Aerobic Conditions To Form dA-FA-OMe

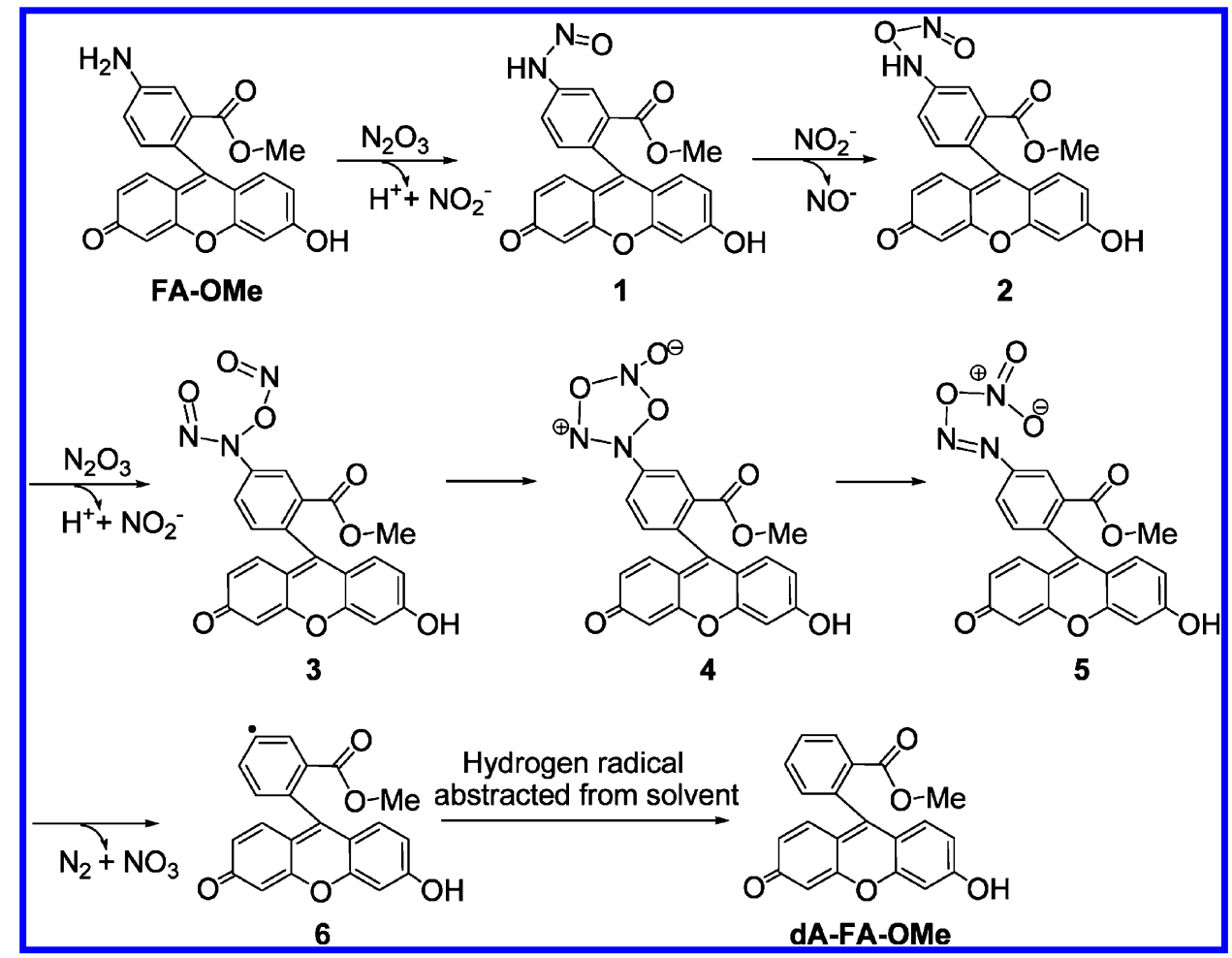

the cells were washed three times with $2 \mathrm{~mL}$ of fresh PBS and then bathed in $2 \mathrm{~mL}$ of fresh PBS while on the fluorescence microscope. This process was repeated every $10 \mathrm{~min}$ during imaging.

2.9. Cell Viability Studies. The Raw 264.7 murine macrophages were grown in 96-well plates at an initial density of $10^{5}$ cells per well for $24 \mathrm{~h}$. Subsequently, different concentrations of FA-OMe were incubated with Raw 264.7 murine macrophages at $37{ }^{\circ} \mathrm{C}$ for $24 \mathrm{~h}$. After incubation, the supernatant was removed and the cells were washed three times with PBS buffer solution. Cell viability was evaluated using the 3-(4,5-dimethylthiazol-2-yl)-2,5-diphenyltetrazolium bromide (MTT) reduction assay. Briefly, MTT $(20 \mu \mathrm{L}, 5 \mathrm{mg}$ $\left.\mathrm{mL}^{-1}\right)$ was added to each well. After $4 \mathrm{~h}$ of incubation, each well was treated with dimethyl sulfoxide $(100 \mu \mathrm{L})$ with pipetting. The absorbance at $570 \mathrm{~nm}$ was measured on a plate reader. Each treatment was done in six wells, and the experiments were repeated three times. Cell viability was calculated relative to the absorbance of the control for each treatment. The viability of untreated cells was assumed to be $100 \%$.

\section{RESULTS AND DISCUSSION}

3.1. Synthesis, Characterization, and Proposed Mechanism. FA-OMe was easily prepared by refluxing the $\mathrm{MeOH}$ solution of fluoresceinamine with acid catalyst. To grossly observe the optical behavior of FA-OMe, NO gas was bubbled into an aqueous solution of FA-OMe. The solution immediately changed from yellow to light green. This indeed qualitatively establishes that FA-OMe is reactive toward NO. The reaction product dA-FA-OMe was purified, and the structure was elucidated using NMR spectroscopy and mass spectrometry. Thus, FA-OMe can detect NO and produce strongly fluorescent dA-FA-OMe through reductive deamination of FA-OMe.

The ${ }^{1} \mathrm{H}$ NMR spectra of FA-OMe and dA-FA-OMe are shown in Figure 2. FA-OMe and dA-FA-OMe exhibit the expected idealized $C_{2 v}$ symmetry in solution due to the exchange process of the carbonyl and hydroxyl of the xanthene moiety. The lack of an apparent broad signal at around 11.0 ppm shows that the hydroxyls of FA-OMe and dA-FA-OMe may be deprotonated in the solution. Thus, eight types of protons in different chemical environments for FA-OMe $(a-h)$ and dA-FA-OMe $\left(\mathrm{a}^{\prime}-\mathrm{h}^{\prime}\right)$ are observed, respectively. As shown in Figure $2 \mathrm{~B}, \mathrm{~b}^{\prime}$ and $\mathrm{c}^{\prime}$ signals of $\mathrm{dA}-\mathrm{FA}$-OMe present the splitting pattern of a doublet of doublets $(\mathrm{dd}, J=7.5$ and 7.8 $\mathrm{Hz}$ ) at 7.80 and $7.71 \mathrm{ppm}$, respectively. In addition, the $\mathrm{f}^{\prime}$ signal merging with the $\mathrm{g}^{\prime}$ signal is a doublet signal, like the e signal of FA-OMe, as shown in Figure 2A. The primary amino group of FA-OMe, because of its electron-donating effect, increases the valence electron density around the protons of the phenyl ring. Therefore, the protons $(a-c)$ are shielded higher than those of dA-FA-OMe $\left(a^{\prime}-d^{\prime}\right)$ without an amino group. This result makes the $a-c$ signals shift upfield in comparison to $a^{\prime}-d^{\prime}$ signals. The ${ }^{13} \mathrm{C}$ NMR spectra of FA-OMe and dA-FA-OMe display 15 resonance signals, respectively, which indeed correspond with the $C_{2 v}$ symmetry (Figure $S 1$ in the Supporting Information).

The reaction mechanism for deamination of FA-OMe is proposed as shown in Scheme 1. First, the primary amino group of FA-OMe is nitrosylated by $\mathrm{N}_{2} \mathrm{O}_{3}$, which forms by the autoxidation of $\mathrm{NO}^{23}$ to produce the $\mathrm{N}$-nitrosoamine intermediate $1 .{ }^{9 \mathrm{~g}}$ Subsequently, nitrite ion reacts with 1 to produce the nitramine intermediate. ${ }^{24} \mathrm{Afterward}$, the secondary amine of 2 is nitrosylated by $\mathrm{N}_{2} \mathrm{O}_{3}$ to form the $\mathrm{N}$-nitroso nitramine intermediate 3 , and then the $N$-nitroso nitramine moiety of 3 rearranges into the diazo nitrate moiety to form the diazo nitrate intermediate 5 . It was reported that some diazo nitrates could decompose by homolytic bond rupture to form the corresponding radicals, nitrogen gas, and nitrate radical. ${ }^{25}$ Thus, the diazo nitrate intermediate 5 homolytically decomposes to give the fluoresceinyl radical 6 , which readily abstracts hydrogen from the solvent to give the deaminated product dAFA-OMe. According to the ESI-mass spectrum of FA-OMe reacting with $\mathrm{NO}(\mathrm{aq})$ for $1.0 \mathrm{~min}$ under aerobic conditions 
(Figure S2 in the Supporting Information), the peaks corresponding to the proposed intermediates $\mathbf{1}, \mathbf{2}$, and 5 (or 3 and 4) were certainly observed. These results supported the proposed mechanism. However, further experimental studies are necessary to completely demonstrate our proposed mechanism. In other words, the proposed intermediates or their derivatives formed by a specific reagent (trap) should be isolated and fully characterized. The related experimental studies are currently under investigation.

3.2. Computations. A computational study was carried out using the Gaussian 09 program to understand the theoretical aspects of the change in fluorescence intensity. Density functional theory (DFT) calculations at the B3LYP/6-31+ $+\mathrm{G}^{* *}$ level were applied to obtain the optimized geometries and energy levels of frontier molecular orbitals of the components forming FA-OMe and dA-FA-OMe (methyl 3aminobenzoate, methyl benzoate, and xanthene). As shown in Figure 3, the highest occupied molecular orbital (HOMO) of

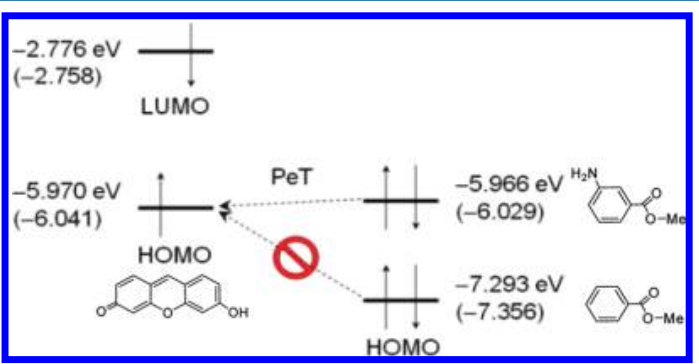

Figure 3. Energy levels of the methyl 3-aminobenzoate, methyl benzoate, and xanthene moieties. The values in parentheses were derived from the calculations considering the aqueous environment.

the methyl 3-aminobenzoate moiety (electron donor) matches that of the xanthene moiety (electron acceptor); therefore, when the latter is photoexcited, the intramolecular electron transfer from the methyl 3-aminobenzoate moiety to the xanthene moiety is energetically favorable. In contrast, the HOMO of the methyl benzoate moiety is significantly lower than that of the xanthene moiety; consequently, the intramolecular electron transfer from the former to the latter is energetically unfavorable. The DFT calculations indicate that the behavior of the NO turn-on fluorescence of FA-OMe is associated with the PeT phenomenon.

3.3. Optical Properties of FA-OMe and dA-FA-OMe. The fluorescence properties of FA-OMe and dA-FA-OMe are summarized in Table 1. The ultraviolet-visible (UV/vis) spectrum profiles of FA-OMe and dA-FA-OMe are not significantly different, as shown in Figure 4. However, the quantum yield of dA-FA-OMe is approximately 59-fold higher than that of FA-OMe. Consequently, even a small amount of dA-FA-OMe formed in the reaction of FA-OMe with NO can produce remarkable fluorescence enhancement.

Table 1. Fluorescence Quantum Yields $\left(\boldsymbol{\Phi}_{\mathrm{fl}}\right)$ and Absorption and Emission Maxima $\left(\lambda_{\mathrm{abs}}, \lambda_{\mathrm{em}}\right)$ of FA-OMe and dA-FA-

$\mathrm{OMe}$ in $0.1 \mathrm{M} \mathrm{NaOH}(\mathrm{aq})$ Determined by Comparison with a Fluorescein Standard Solution $\left(\Phi_{\mathrm{fl}}=0.95\right.$ in $0.1 \mathrm{M}$ $\mathrm{NaOH}(\mathrm{aq})$ )

$\begin{array}{lccc}\text { compd } & \lambda_{\text {abs }}(\mathrm{nm}) & \lambda_{\text {em }}(\mathrm{nm}) & \Phi_{\mathrm{fl}}(\%) \\ \text { FA-OMe } & 488 & 518 & 1.5 \\ \text { dA-FA-OMe } & 490 & 514 & 88.8\end{array}$

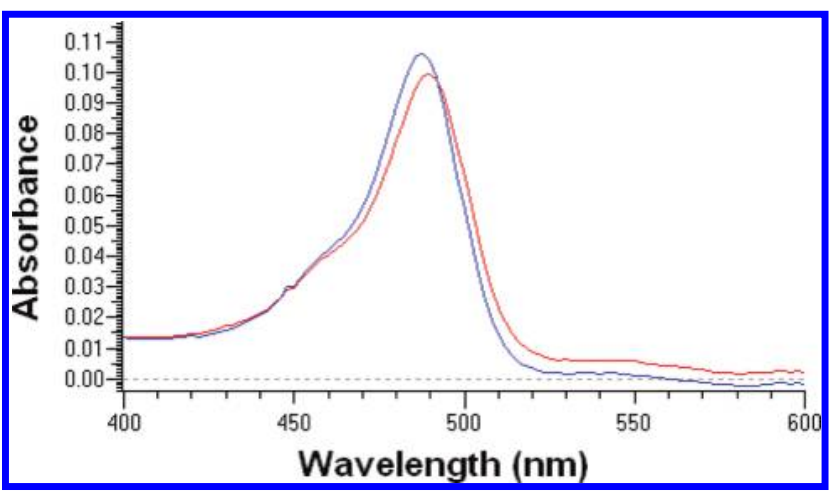

Figure 4. Absorption spectra of FA-OMe $(1 \mu \mathrm{M}$, blue line $)$ and dAFA-OMe $(1 \mu \mathrm{M}$, red line) in $0.1 \mathrm{M} \mathrm{NaOH}(\mathrm{aq})$.

3.4. Stability of FA-OMe and dA-FA-OMe. Since the stability of probes under various $\mathrm{pH}$ conditions concerns the biological applicability, the effects of $\mathrm{pH}$ on the fluorescence intensities of FA-OMe and $\mathrm{dA}-\mathrm{FA}-\mathrm{OMe}$ were investigated at different $\mathrm{pHs}$ ranging from 6.5 to 10 , as shown in Figure 5. A

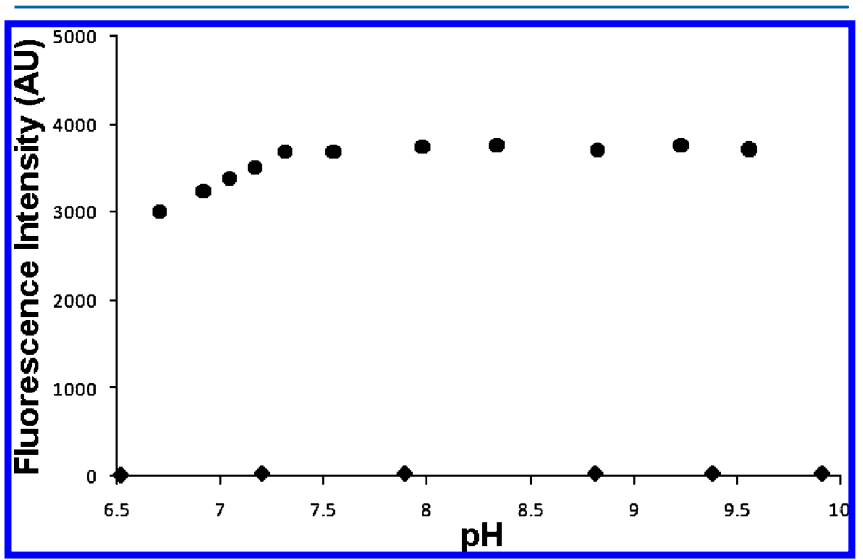

Figure 5. $\mathrm{pH}$ dependence of the fluorescence intensities of $20 \mu \mathrm{M}$ FA$\mathrm{OMe}(\bullet)$ and dA-FA-OMe $(\bullet)$ in $100 \mathrm{mM}$ HEPES buffer at $25.0 \pm$ $0.1{ }^{\circ} \mathrm{C}$. The fluorescence intensities were detected at $524 \mathrm{~nm}$ with excitation at $460 \mathrm{~nm}$.

significant change in the fluorescence intensity of FA-OMe was not observed with an increase in $\mathrm{pH}$ from 6.6 to 10 . In contrast, the gradually increasing fluorescence intensity of dA-FA-OMe reached a maximum value at $\mathrm{pH}$ 7.4. However, the fluorescence intensity ratio of dA-FA-OMe to FA-OMe shows high values between $\mathrm{pH} 6.5$ and 10. This result indicates that FA-OMe can be used as an efficient fluorescent probe for the detection of NO under physiological conditions.

3.5. Concentration and Time Dependence of FA-OMe Reacting with NO. The concentration- and time-dependent reactions between FA-OMe and NO were carried out in 100 $\mathrm{mM}$ HEPES buffer at $\mathrm{pH}$ 7.4. To $50 \mu \mathrm{M}$ FA-OMe solutions were added different amounts of the NO stock solution (1.8 $\mathrm{mM}$ ). The fluorescence intensity at $524 \mathrm{~nm}$ is enhanced upon increasing the amount of $\mathrm{NO}(\mathrm{aq})$, as shown in Figure 6 . Furthermore, the time-dependent fluorescence turn-on of FAOMe shows a highly uniform pattern with different amounts of NO, as shown in Figure 7. The fluorescence intensities at 524 $\mathrm{nm}$ increase with time and reach a plateau within about $20 \mathrm{~min}$. These results indicate that the NO concentration and reaction time influence proportionally the turn-on fluorescent intensity of FA-OMe. In addition, judging from Figure 6, the 


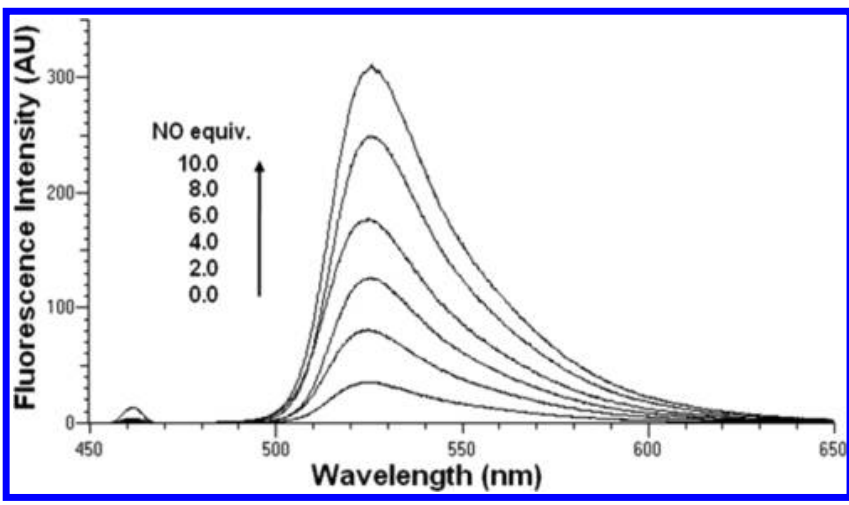

Figure 6. Fluorescence emission spectra of FA-OMe $(50 \mu \mathrm{M})$ upon reaction with various amounts of $\mathrm{NO}(\mathrm{aq})$ in $100 \mathrm{mM}$ HEPES buffer of $\mathrm{pH} 7.4$ at $25.0 \pm 0.1{ }^{\circ} \mathrm{C}\left(\lambda_{\mathrm{ex}} 460 \mathrm{~nm}, \lambda_{\mathrm{em}} 524 \mathrm{~nm}\right)$.

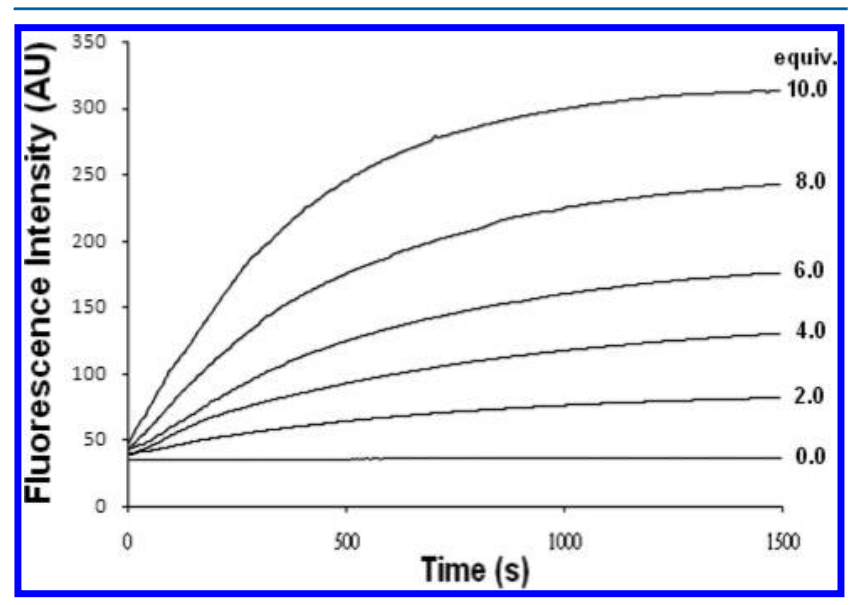

Figure 7. Time dependence of the fluorescence intensity of $50 \mu \mathrm{M}$ FA-OMe in pH 7.4 $100 \mathrm{mM}$ HEPES buffer with different amounts of the NO stock solution. The fluorescence intensities were detected at $524 \mathrm{~nm}$ with excitation at $460 \mathrm{~nm}$ at $25.0 \pm 0.1{ }^{\circ} \mathrm{C}$.

enhancement in fluorescence intensity presents a linear correlation with concentration. The detection limit for NO, calculated as the concentration of NO at which the fluorescence signal is equal to the blank value plus a 3 -fold standard deviation, was estimated as $\sim 44 \mathrm{nM}$. Therefore, FA-OMe could be used for detecting endogenous NO in living cells.

3.6. Selectivity. The high specificity of the NO probe is imperative for its application in understanding the diverse biological roles played by NO. Therefore, the fluorescence intensities of FA-OMe in the presence of a series of possible competitive reactive oxygen species (ROS), reactive nitrogen species (RNS), AA, and DHA at up to 100-fold excess were examined under the same conditions. As shown in Figure 8, no detectable responses for these agents were observed. It was reported that the commercially available NO probe DAF- ${ }^{9 \mathrm{~b}}$ reacted with DHA or AA and turned on the probe under physiological conditions. ${ }^{21}$ Additionally, in the presence of $\mathrm{H}_{2} \mathrm{O}_{2}$ /peroxidase, $\mathrm{OONO}^{-}$, or ${ }^{\bullet} \mathrm{OH}$, the $o$-diaminophenyl group is oxidized into an unstable arylaminyl radical, which can directly combine with $\mathrm{NO}$ to form triazole. ${ }^{26}$ The better selectivity of FA-OMe for NO, in contrast to that of DAF-2, may be attributed to its less electron rich NO-reactive moiety. However, because of its highly electron rich $o$-diaminophenyl group, DAF-2 has a comparatively high reaction rate for NO according to the time-dependent experiments of DAF-2 and FA-OMe with 10 equiv of $\mathrm{NO}(\mathrm{aq})$ (Figure $\mathrm{S} 3$ in the

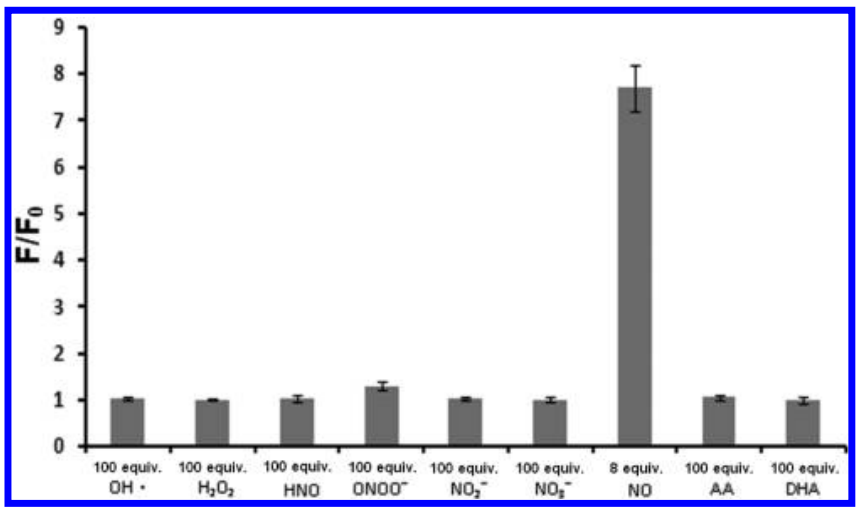

Figure 8. Selectivity of FA-OMe $(20 \mu \mathrm{M})$ for NO over other reactive oxygen and nitrogen species: normalized fluorescence response after 2 $h$ relative to the emission of the probe in $100 \mathrm{mM}$ HEPES buffer at $\mathrm{pH}$ 7.4 and $25.0 \pm 0.1{ }^{\circ} \mathrm{C}\left(\lambda_{\mathrm{ex}} 460 \mathrm{~nm}, \lambda_{\mathrm{em}} 524 \mathrm{~nm}\right)$.

Supporting Information). In addition, dA-FA-OMe formation requires two $\mathrm{N}_{2} \mathrm{O}_{3}$ molecules, as shown in Scheme 1, but the formation of the triazole derivative DAF-2T only needs one $\mathrm{N}_{2} \mathrm{O}_{3}$ molecule. ${ }^{9 g}$ This assertion may also explain why the reactivity and fluorescent intensity of DAF-2 for NO are higher than those of FA-OMe.

3.7. Fluorescence Imaging of NO in Living Cells. The cytotoxicity of FA-OMe was investigated by incubating various concentrations of FA-OMe with Raw 264.7 murine macrophages. After $24 \mathrm{~h}$, cell viability was examined by the 3-(4,5dimethylthiazol-2-yl)-2,5-diphenyltetrazolium bromide (MTT) assay and the results demonstrated that FA-OMe displayed low cytotoxicity to Raw 264.7 murine macrophages, as shown in Figure 9. To evaluate the utility of FA-OMe for the detection of endogenously generated NO, fluorescence microscopic imaging of biologically produced NO in Raw 264.7 murine macrophages was performed. The Raw 264.7 murine macrophages were stimulated by lipopolysaccharide (LPS; $0.5 \mu \mathrm{g} \mathrm{mL}^{-1}$ ) for $4 \mathrm{~h}$ and then incubated with $10 \mu \mathrm{M}$ FA-OMe for an additional 4 and $8 \mathrm{~h}$. In a control experiment, cells were incubated for $8 \mathrm{~h}$ with $10 \mu \mathrm{M}$ FA-OMe in the absence of LPS. As shown in Figure 10B,C, a visible increase in fluorescence was observed over $4-8 \mathrm{~h}$ following FA-OMe incubation $(8-12 \mathrm{~h}$ after induction of iNOS), which was not observed in the control cells (Figure 10A). These results indicate that FA-OMe can detect endogenously produced NO. To test the cell trappability of FAOMe, Raw 264.7 murine macrophages prestimulated with 1.25 $\mu \mathrm{g} \mathrm{mL}^{-1}$ LPS were incubated with $10 \mu \mathrm{M}$ FA-OMe for $8 \mathrm{~h}$ and then washed and imaged by the fluorescence microscope four times over the course of $30 \mathrm{~min}$, where a minimal change in fluorescence intensity was observed, as shown in Figure 11. Therefore, FA-OMe has cell-trappable characteristics. ${ }^{13}$ Since the ester groups can be cleaved by intracellular esterases to give carboxylates under physiological $\mathrm{pH}$ conditions to restrict recrossing of the cell membrane, the cell trappability may be caused by hydrolyzing FA-OMe into FA-OMe-carboxylate, which may react with $\mathrm{NO} / \mathrm{O}_{2}$ to form dA-FA-OMe-carboxylate. To prove that the turn-on fluorescence would be not achieved by FA-OMe-carboxylate in living cells, $\mathrm{pH}$-dependent studies of FA-OMe and fluoresceinamine, which would transform into FA-OMe-carboxylate in aqueous solutions above $\mathrm{pH} 4.0,{ }^{12 \mathrm{a}}$ were undertaken in the $\mathrm{pH}$ range of 6.5-10, as shown in Figure 12. The fluorescence intensities are not apparently different at this $\mathrm{pH}$ range. These results show that FA-OMe-carboxylate cannot turn on the fluorescence. On the basis of the formation 


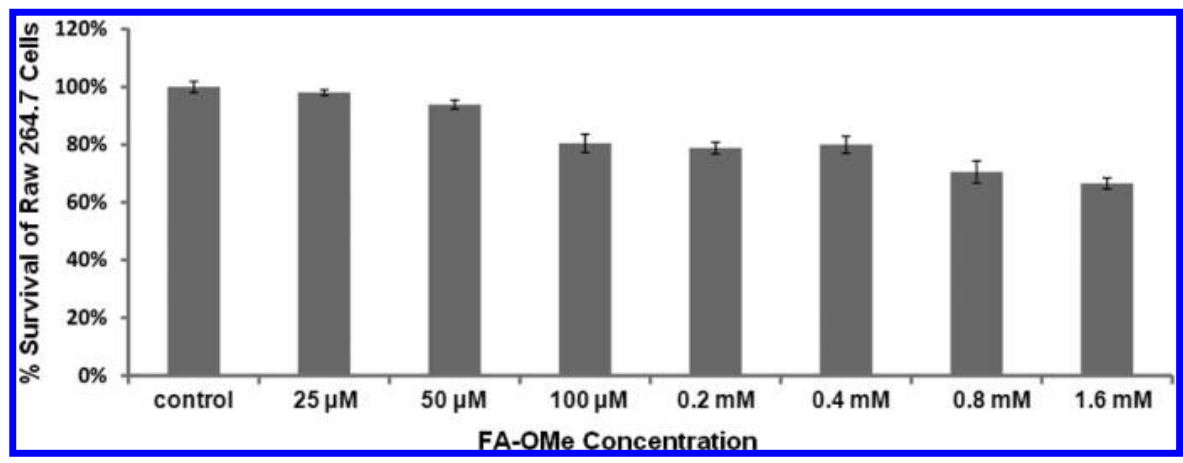

Figure 9. MTT assay on Raw 264.7 murine macrophages treated with different concentrations of FA-OMe for $24 \mathrm{~h}$.

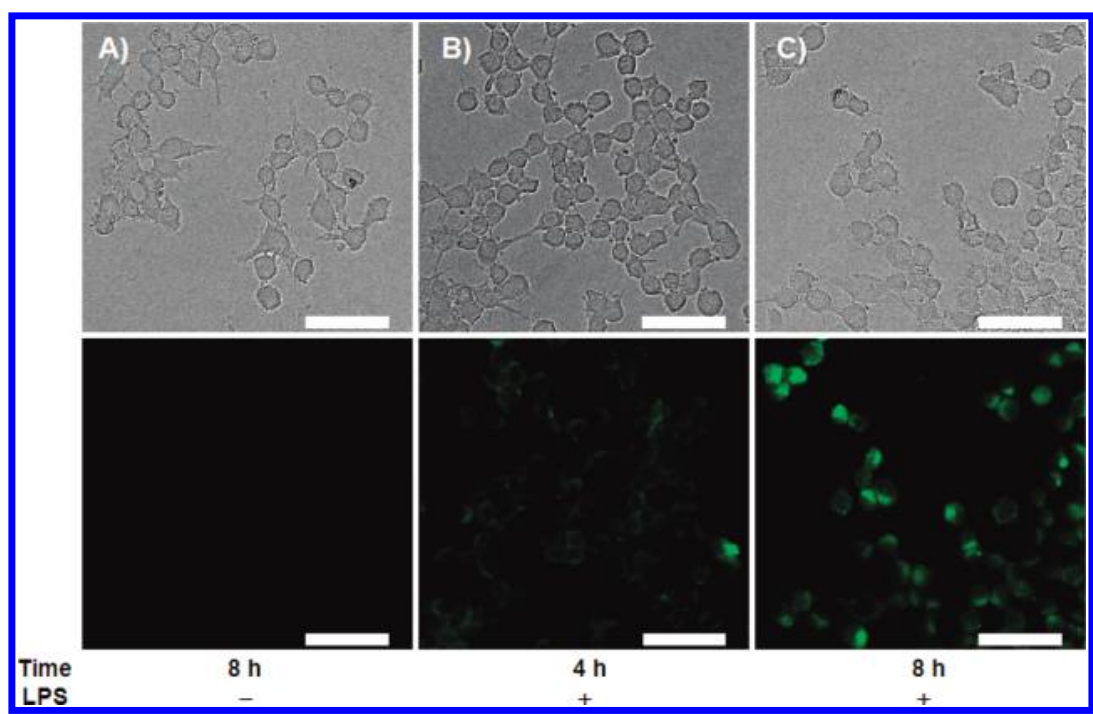

Figure 10. Endogenous NO detection in Raw 264.7 murine macrophages by FA-OMe (10 $\mu \mathrm{M})$ : (top) DIC images; (bottom) fluorescence. FAOMe incubation with cells for (A) $8 \mathrm{~h}$ without LPS prestimulation, (B) $4 \mathrm{~h}$ with LPS $\left.(0.5 \mu \mathrm{g} \mathrm{mL})^{-1}\right)$ prestimulation for $4 \mathrm{~h}$, and (C) $8 \mathrm{~h}$ with LPS $\left(0.5 \mu \mathrm{g} \mathrm{mL}^{-1}\right)$ prestimulation for $4 \mathrm{~h}$. The scale bar represents $50 \mu \mathrm{m}$.

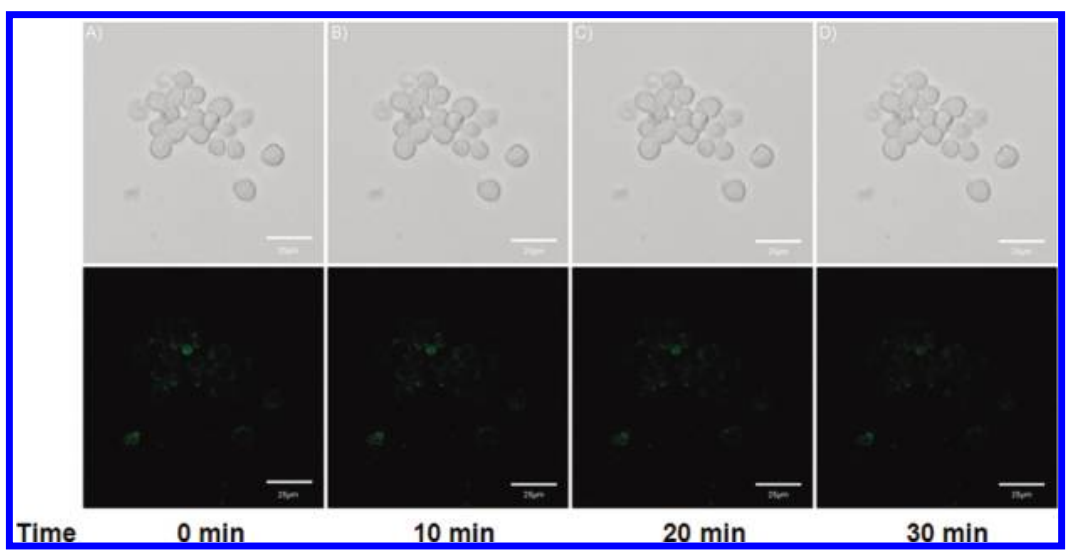

Figure 11. FA-OMe diffusion/localization in Raw 264.7 murine macrophages: (top) DIC images; (bottom) fluorescence. After each image, the cells were washed three times with $2 \mathrm{~mL}$ of PBS. [FA-OMe] $=10 \mu \mathrm{M}$, [LPS] $=1.25 \mu \mathrm{g} \mathrm{mL}^{-1}$, scale bars $25 \mu \mathrm{m}$.

of strongly fluorescent fluorescein, which would transform into dA-FA-OMe-carboxylate in aqueous solutions above $\mathrm{pH} 4.0$, in the reaction of fluoresceinamine with $\mathrm{NO} / \mathrm{O}_{2}$ under neutral $\mathrm{pH}$ conditions, FA-OMe-carboxylate can react with $\mathrm{NO} / \mathrm{O}_{2}$ to generate dA-FA-OMe-carboxylate in living cells. Therefore, FA$\mathrm{OMe}$ can be used as a fluorescent probe for the detection of NO formed in living cells.

\section{SUMMARY}

In this study, we have demonstrated the first example of an NO turn-on fluorescent probe based on reductive deamination of an aromatic primary monoamine. The DFT calculations of dA-FA$\mathrm{OMe}$ relative to $\mathrm{FA}-\mathrm{OMe}$ suggest that the fluorescence enhancement is associated with the PeT phenomenon. The high quantum yield of deaminated product shows that even a small deamination induced by $\mathrm{NO}$ can result in significant fluorescence enhancement. In addition, the use of a less 


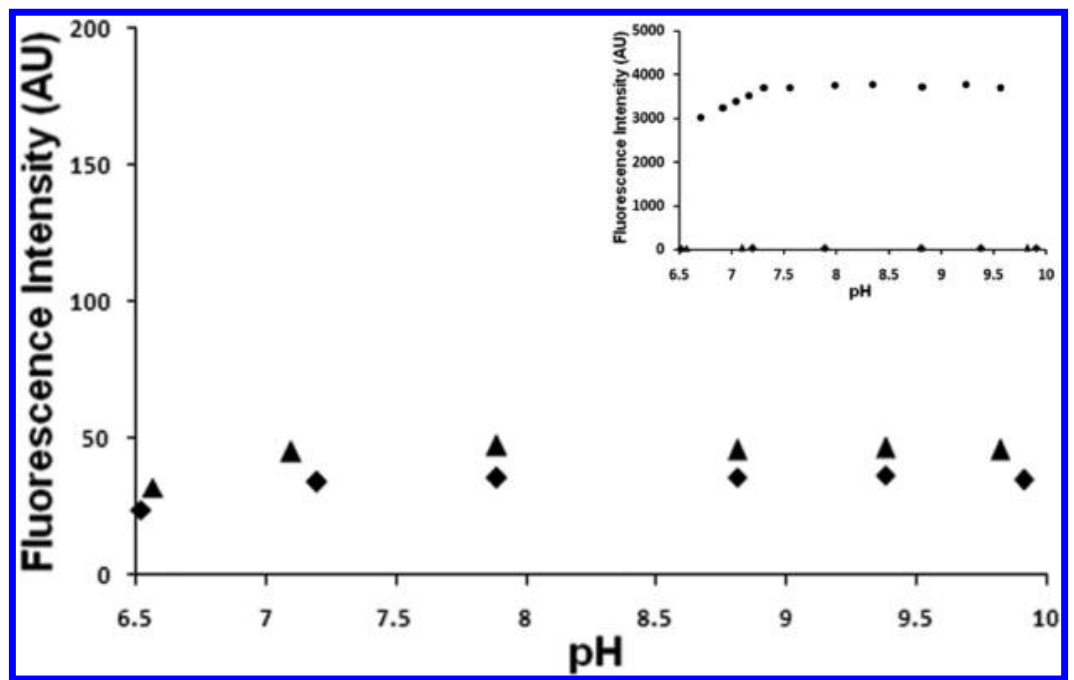

Figure 12. $\mathrm{pH}$ dependence of the fluorescence intensities of $20 \mu \mathrm{M}$ fluoresceinamine $(\boldsymbol{\Delta})$ and FA-OMe $(\boldsymbol{\nabla})$ in $100 \mathrm{mM}$ HEPES buffer at $25.0 \pm 0.1$ ${ }^{\circ} \mathrm{C}$. The fluorescence intensities were detected at $524 \mathrm{~nm}$ with excitation at $460 \mathrm{~nm}$. Inset: comparison to that of $20 \mu \mathrm{M}$ dA-FA-OMe $(\mathbf{O})$ in 100 $\mathrm{mM}$ HEPES buffer at $25.0 \pm 0.1{ }^{\circ} \mathrm{C}$.

electron rich NO-reactive moiety renders FA-OMe high specificity for $\mathrm{NO}$ over other reactive oxygen/nitrogen species and substances that hinder the existing probes from sensing NO. Furthermore, the aqueous solubility and high fluorescence stability of FA-OMe and dA-FA-OMe over a wide range of $\mathrm{pH}$ ensure its potential application for NO bioimaging, which was successfully performed in Raw 264.7 murine macrophages. The results obtained in the present study demonstrate the viability of developing a series of $\mathrm{NO}$ probes based on reductive deamination of an aromatic primary monoamine.

\section{ASSOCIATED CONTENT}

\section{S Supporting Information}

Figures giving ${ }^{13} \mathrm{C}$ NMR spectra for FA-OMe and dA-FA-OMe, ESI-mass spectrum of FA-OMe reacting with $\mathrm{NO}(\mathrm{aq})$, and time-dependent studies of DAF-2 and FA-OMe. This material is available free of charge via the Internet at http://pubs.acs.org.

\section{AUTHOR INFORMATION}

\section{Corresponding Author}

*Tel: 886-3-5712121 ext 56972. Fax: 886-3-5729288. E-mail: ymwang@mail.nctu.edu.tw.

Notes

The authors declare no competing financial interest.

\section{ACKNOWLEDGMENTS}

Funding from the National Science Council of Taiwan (NSC 100-2627-M-009-002) and from National Chiao Tung University and the Ministry of Education of Taiwan (Aim for the Top University Plan) are gratefully acknowledged.

\section{REFERENCES}

(1) (a) Palmer, R. M. J.; Ferrige, A. G.; Moncada, S. Nature 1987, 327, 524. (b) Nitric Oxide: Biology and Pathobiology, 1st ed.; Ignarro, L. J., Ed.; Academic Press: San Diego, CA, 2000. (c) Nitric Oxide; Mayer, B., Ed.; Springer: Berlin, 2000. (d) Butler, A. R.; Williams, D. L. H. Chem. Soc. Rev. 1993, 22, 233. (e) Furchgott, R. F. Angew. Chem. Int. Ed. 1999, 38, 1870. (f) Wink, D. A.; Vodovotz, Y.; Laval, J.; Laval, F.; Dewhirst, M. W.; Mitchell, J. B. Carcinogenesis 1998, 19, 711. (g) Murad, F. Angew. Chem., Int. Ed. 1999, 38, 1856. (h) Zimmet, J. M.; Hare, J. M. Circulation 2006, 114, 1531.
(2) Brien, J. F.; McLaughlin, B. E.; Nakatsu, K.; Marks, G. S. $\underline{\text { Methods }}$ Enzvmol. 1996, 268, 83.

(3) (a) Green, L. C.; Wagner, D. A.; Glogowski, J.; Skipper, P. L.; Wishnok, J. S.; Tannenbaum, S. R. Anal. Biochem. 1982, 126, 131. (b) Nims, R. W.; Darbyshire, J. F.; Saavedra, J. E.; Christodoulou, D.; Hanbauer, I.; Cox, G. W.; Grisham, M. B.; Laval, F.; Cook, J. A.; Krishna, M. C.; Wink, D. A. Methods 1995, 7, 48. (c) Ridnour, L. A.; Sim, J. E.; Hayward, M. A.; Wink, D. A.; Martin, S. M.; Buettner, G. R; Spitz, D. R. Anal. Biochem. 2000, 281, 223. (d) Brown, F.; Finnerty, N. J.; Bolger, F. B.; Millar, J.; Lowry, J. P. Anal. Bioanal. Chem. 2005, 381, 964.

(4) (a) Kosaka, H.; Watanabe, M.; Yoshihara, H.; Harada, N.; Shiga, T. Biochem. Biophys. Res. Commun. 1992, 184, 1119. (b) Katayama, Y.; Soh, N.; Maeda, M. ChemPhvsChem 2001, 2, 655.

(5) (a) Malinski, T.; Taha, Z. Nature 1992, 358, 676. (b) Ichimori, K.; Shida, I. H.; Fukahori, M.; Nakazawa, H.; Murakami, E. Rev. Sci. Instrum. 1994, 65, 2714. (c) Bedioui, F.; Villeneuve, N. Electroanalvsis 2003, 15, 5 .

(6) (a) Kojima, H.; Urano, Y.; Kikuchi, K.; Higuchi, T.; Hirata, Y.; Nagano, T. Angew. Chem., Int. Ed. 1999, 38, 3209. (b) Franz, K. J.; Singh, N.; Lippard, S. I. Angew. Chem. Int. Ed. 2000, 39, 2120. (c) Soh, N.; Katayama, Y.; Meada, M. Analvst 2001, 126, 564. (d) Miller, E. W.; Chang, C. I. Curr. Opin. Chem. Biol. 2007, 11, 620.

(7) (a) Yang, Y.; Seidlits, S. K.; Adams, M. M.; Lynch, V. M.; Schmidt, C. E.; Anslyn, E. V.; Shear, J. B. J. Am. Chem. Soc. 2010, 132, 13114. (b) Kim, J. H.; Heller, D. A.; Barone, P. W.; Song, C.; Zhang, J.; Trudel, L. J.; Wogan, G. N.; Tannenbaum, S. R.; Strano, M. S. Nat. Chem. 2009, 1, 473. (c) Wang, S.; Han, M. Y.; Huang, D. I. Am. Chem. Soc. 2009, 131, 11692. (d) Zheng, H.; Shang, G. Q.; Yang, S. Y.; Gao, X.; Xu, J. G. Org. Lett. 2008, 10, 2357. (e) Meineke, P.; Rauen, U.; de Groot, H.; Korth, H.-G.; Sustmann, R. Chem. Eur. I. 1999, 5, 1738 (f) Heiduschka, P.; Thanos, S. Neuroreport 1998, 9, 4051. (g) Gabe, Y.; Urano, Y.; Kikuchi, K.; Kojima, H.; Nagano, T. I. Am. Chem. Soc. 2004, 126, 3357. (h) Lim, M. H.; Xu, D.; Lippard, S. I. Nat. Chem. Biol. 2006, 2, 375. (i) Lim, M. H.; Wong, B. A.; Pitcock, W. H., Jr.; Mokshagundam, D.; Baik, M. H.; Lippard, S. J. J. Am. Chem. Soc. 2006, 128, 14363. (j) Tonzetich, Z. J.; McQuade, L. E.; Lippard, S. I. Inorg. Chem. 2010, 49, 6338. (k) Duarte, A. J.; Esteves da Silva, J. C. G. Sensors 2010, 10, 1661. (1) Mondal, B.; Kumar, P.; Ghosh, P.; Kalita, A. Chem. Commun. 2011, 47, 2964. (m) Sun, C. D.; Shi, W.; Song, Y. C.; Chen, W.; Ma, H. M. Chem. Commun. 2011, 47, 8638. (n) Meineke, P.; Rauen, U.; de Groot, H.; Korth, H.-G.; Sustmann, R. Biol. Chem. 2000, 381, 575. (o) Hornig, F. S.; Korth, H.-G.; Rauen, U.; de Groot, H.; Sustmann, R. Helv. Chim. Acta 2006, 89, 2281. (p) Düppe, P. M.; Talbierski, P. M.; Hornig, F. S.; Rauen, U.; Korth, H.-G.; Wille, T.; 
Boese, R.; Omlor, T.; de Groot, H.; Sustmann, R. Chem. Eur. J. 2010, 16, 11121 .

(8) Nagano, T.; Yoshimura, T. Chem. Rev. 2002, 102, 1235.

(9) (a) Kojima, H.; Hirotani, M.; Nakatsubo, N.; Kikuchi, K.; Urano, Y.; Higuchi, T.; Hirata, Y.; Nagano, T. Anal. Chem. 2001, 73, 1967.

(b) Kojima, H.; Nakatsubo, N.; Kikuchi, K.; Kawahara, S.; Kirino, Y.; Nagoshi, H.; Hirata, Y.; Nagano, T. Anal. Chem. 1998, 70, 2446. (c) Sasaki, E.; Kojima, H.; Nishimatsu, H.; Urano, Y.; Kikuchi, K.; Hirata, Y.; Nagano, T. I. Am. Chem. Soc. 2005, 127, 3684. (d) Zhang, R.; Ye, Z. Q.; Wang, G. L.; Zhang, W. Z.; Yuan, J. L. Chem. Eur. I. 2010, 16, 6884. (e) Chen, Y. G.; Guo, W. H.; Ye, Z. Q.; Wang, G. L.; Yuan, J. L. Chem. Commun. 2011, 47, 6266. (f) Ye, Z. Q.; Chen, J. X.; Wang, G. L.; Yuan, J. L. Anal. Chem. 2011, 83, 4163. (g) Nakatsubo, N.; Kojima, H.; Kikuchi, K.; Nagoshi, H.; Hirata, Y.; Maeda, D.; Imai, Y.; Irimura, T.; Nagano, T. FEBS Lett. 1998, 427, 263.

(10) (a) Caulfield, J. L.; Wishnok, J. S.; Tannenbaum, S. R. J. Biol. Chem. 1998, 273, 12689. (b) Nagano, T.; Takizawa, H.; Hirobe, $\underline{M}$. Tetrahedron Lett. 1995, 36, 8239.

(11) (a) Itoh, T.; Matsuya, Y.; Nagata, K.; Ohsawa, A. Tetrahedron Lett. 1996, 37, 4165. (b) Itoh, T.; Nagata, K.; Matsuya, Y.; Miyazaki, M.; Ohsawa, A. I. Org. Chem. 1997, 62, 3582.

(12) (a) Munkholm, C.; Parkinson, D. R.; Walt, D. R. J. Am. Chem. Soc. 1990, 112, 2608. (b) Uryga-Polowy, V.; Kosslick, D.; Freund, C.; Rademann, I. ChemBioChem 2008, 9, 2452.

(13) (a) Pluth, M. D.; McQuade, L. E.; Lippard, S. J. Org. Lett. 2010, 12, 2318. (b) Tsien, R. Y. Nature 1981, 290, 527. (c) Izumi, S.; Urano, Y.; Hanaoka, K.; Terai, T.; Nagano, T. I. Am. Chem. Soc. 2009, 131, 10189.

(14) Works, C. F.; Jocher, C. J.; Bart, G. D.; Bu, X.; Ford, P. C. Inorg. Chem. 2002, 41, 3728.

(15) Sigmund, H.; Pfleiderer, W. Helv. Chim. Acta 2003, 86, 2299.

(16) (a) Ouyang, J.; Hong, H.; Shen, C.; Zhao, Y.; Ouyang, C. G.; Dong, L.; Zhu, J. U.; Guo, Z. J.; Zeng, K.; Chen, J. G.; Zhang, C. Y.; Zhang, J. F. Free Radic. Biol. Med. 2008, 45, 1426. (b) Huang, K. J.; Wang, H.; Ma, M.; Zhang, X.; Zhang, H. S. Nitric Oxide 2007, 16, 36. (c) Noyes, W. A. I. Am. Chem. Soc. 1925, 47, 2170.

(17) Miyamoto, S.; Martinez, G. R.; Martins, A. P. B; Medeiros, M. H. G.; Mascio, P. D. J. Am. Chem. Soc. 2003, 125, 4510.

(18) Irvine, J. C.; Favaloro, J. L.; Kemp-Harper, B. K. Hypertension 2003, 41, 1301.

(19) Setsukinai, K.; Urano, Y.; Kakinuma, K.; Majima, H. J.; Nagano, T. J. Biol. Chem. 2003, 278, 3170.

(20) Lei, B.; Adachi, N.; Arai, T. Brain Research Protocols 1998, 3, 33.

(21) (a) Zhang, X.; Kim, W. S.; Hatcher, N.; Potgieter, K.; Moroz, L. L.; Gillette, R.; Sweedler, J. V. J. Biol. Chem. 2002, 277, 48472. (b) Ye, X.; Rubakhin, S. S.; Sweedler, J. V. I. Neurosci. Methods 2008, 168, 373.

(22) Frisch, M. J.; Trucks, G. W.; Schlegel, H. B.; Scuseria, G. E.; Robb, M. A.; Cheeseman, J. R.; Scalmani, G.; Barone, V.; Mennucci, B.; Petersson, G. A.; Nakatsuji, H.; Caricato, M.; Li, X.; Hratchian, H. P.; Izmaylov, A. F.; Bloino, J.; Zheng, G.; Sonnenberg, J. L.; Hada, M.; Ehara, M.; Toyota, K.; Fukuda, R.; Hasegawa, J.; Ishida, M.; Nakajima, T.; Honda, Y.; Kitao, O.; Nakai, H.; Vreven, T.; Montgomery, J. A., Jr.; Peralta, J. E.; Ogliaro, F.; Bearpark, M.; Heyd, J. J.; Brothers, E.; Kudin, K. N.; Staroverov, V. N.; Kobayashi, R.; Normand, J.; Raghavachari, K.; Rendell, A.; Burant, J. C.; Iyengar, S. S.; Tomasi, J.; Cossi, M.; Rega, N.; Millam, J. M.; Klene, M.; Knox, J. E.; Cross, J. B.; Bakken, V.; Adamo, C.; Jaramillo, J.; Gomperts, R.; Stratmann, R. E.; Yazyev, O.; Austin, A. J.; Cammi, R.; Pomelli, C.; Ochterski, J. W.; Martin, R. L.; Morokuma, K.; Zakrzewski, V. G.; Voth, G. A.; Salvador, P.; Dannenberg, J. J.; Dapprich, S.; Daniels, A. D.; Farkas, O.; Foresman, J. B.; Ortiz, J. V.; Cioslowski, J.; Fox, D. J. Gaussian 09, Revision A.02; Gaussian, Inc., Wallingford, CT, 2009.

(23) Ignarro, L. J.; Fukuto, J. M.; Griscavage, J. M.; Rogers, N. E.; Byrns, R. E. Proc. Natl. Acad. Sci. U.S.A. 1993, 90, 8103.

(24) Wei, W. M.; Zheng, R. H.; Tian, Y.; He, T. J.; He, L.; Chen, D. M.; Liu, F. C. Chin. J. Chem. Phys. 2007, 20, 126.

(25) (a) Tuaillon, J.; Perrot, R. Helv. Chim. Acta 1978, 61, 558.

(b) Brown, J. F., Jr. I. Am. Chem. Soc. 1957, 79, 2480.
(26) (a) Jourd'heuil, D. Free Radical Biol. Med. 2002, 33, 676. (b) Roychowdhury, S.; Luthe, A.; Keilhoff, G.; Wolf, G.; Horn, T. F. W. Glia 2002, 38, 103. (c) Wardman, P. Free Radical Biol. Med. 2007, 43,995 . 